Журнал«Герспективитаінноваціїнаукиљ

(Серія«Гедагогіка», Серія«Гцихологія», Серія«Медицинв»

№2(7) 2022

УДК 378.172

https://doi.org/10.52058/2786-4952-2022-2(7)-610-622

Сахненко Анна Василівна доктор філософії (спеціальність 017 - Фізична культура і спорт), старший викладач, Сумський національний аграрний університет, вул. Г. Кондратьєва, 160, м. Суми, 40000, тел.: (0542) 62-78-16, https://orcid.org/0000-0002-8084-3897

Крот Галина Вікторівна старший викладач, Сумський обласний інститут післядипломної педагогічної освіти, вул. Римського-Корсакова, 5, м. Суми, 40007, тел.: (0542) 33-40-67, https://orcid.org/0000-0002-9933-0362

\title{
КОНЦЕПЦІЯ ДОСЛІДЖЕННЯ АКМЕОЛОГІЧНО СПРЯМОВАНОГО ПРОФЕСІЙНО ОРІЄНТОВАНОГО ФІЗИЧНОГО ВИХОВАННЯ СТУДЕНТІВ АГРАРНИХ СПЕЦІАЛЬНОСТЕЙ 3 ПОЗИЦІЙ СИСТЕМНОГО ТА КОМПЕТЕНТНІСНОГО ПІДХОДІВ
}

Анотація. В умовах реформування системи вищої освіти нашої країни все частіше постає питання відповідності організації фізичного виховання у закладах вищої освіти інтересам студентства і потребам професійної підготовки кваліфікованих спеціалістів, здатних до саморозвитку і самовдосконалення, постійного пошуку нестандартних способів вирішення будь-якого виробничого завдання, використання досягнень науково-технічного прогресу та успішної особистісної і професійної самореалізації.

Саме тому, наукові дослідження сучасних педагогів спрямовані на пошук та аналіз найоптимальніших шляхів покращення організації освітнього процесу у закладах вищої освіти, що будуть детермінувати його зорієнтованість на підготовку майбутніх фахівців до умов професійної діяльності. На думку авторів, у сфері фізичного виховання доцільно звернути увагу на дослідження основних підходів організації професійно орієнтованого фізичного виховання на засадах акмеології.

Основними підходами, з позицій яких здійснювалась розробка концепції обраного напряму дослідження, було визначено системний і компетентнісний підходи. Розробку та обгрунтування концепції дослідження професійно орієнтованого фізичного виховання студентів аграрних спеціальностей на засадах акмеології з позицій системного та компетентнісного підходів було зумовлено розумінням поняття «концепція» як системи доказів певних положень, поглядів на те чи інше явище; способу розуміння, трактування тих чи інших явищ. Водночас, у сучасному науковому просторі термін «концепція» трактується як ідейний і змістовно-цілісний, аргументований і послідовний, завершений виклад оригінальної наукової теорії або версії у розгорнутому вигляді. 
У статті розглянуто ключові поняття компетентнісного та системного підходів і обгрунтовано доцільність їх реалізації у дослідженні та організації акмеологічно спрямованого професійно орієнтованого фізичного виховання у закладах вищої освіти нашої країни.

Ключові слова: акмеологія, професійно орієнтоване фізичне виховання, концепція, підхід, системний, компетентнісний, заклад вищої освіти.

Sakhnenko Anna Vasylivna Doctor of Philosophy (specialty 017 -Physical Culture and Sports), Senior Lecturer, Sumy National Agrarian University G. Kondratieva St., 160, , Sumy, 40000, tel.: (0542) 62-78-16, https://orcid.org/0000-0002-8084-3897

Krot Halyna Viktorivna Senior lecturer, Sumy Regional Institute of Postgraduate Pedagogical Education, Rimsky-Korsakov St., 5, Sumy, 40007, tel.: (0542) 33-40-67, https://orcid.org/0000-0002-9933-0362

\section{RESEARCH CONCEPT OF ACMEOLOGICALLY ORIENTED PROFESSIONALLY BASED PHYSICAL EDUCATION OF AGRICULTURAL SPECIALTIES STUDENTS FROM SYSTEMIC AND COMPETENCE APROACH POSITION}

Abstract. In the reforming context of the higher educational system of our country, the question of physical education compliance at higher educational institutions with the students' interests and the needs for professional training of qualified specialists capable of self-development and self-improvement, constant search for non-standard ways solving any production problem, technical progress and successful personal and professional self-realization.

That is why the research of modern teachers is aimed at finding and analyzing the best ways to improve the educational process organization at higher educational institutions, which will determine its focus on training future professionals to the professional activity conditions. According to the authors, in the physical education field it is advisable to pay attention to the main approaches study to the organization of professionally oriented physical education on the acmeology basis.

The main approaches from the chosen direction research concept developed was defined as systemic and competence approaches. The development and substantiation of the research concept of professionally oriented physical education of agricultural specialities students on the acmeology basis from the systematic and competency approaches standpoint was due to concept understanding as a system of certain positions evidence, views on a phenomenon; understanding way, interpreting certain phenomena. At the same time, in the modern scientific space, the term "concept" is interpreted as an ideological and content-integrated, reasoned and consistent, complete presentation of the original scientific theory or version in an expanded form.

The article considers the key competence and systems approaches concepts and substantiates their implementation feasibility in the study and organization of 
acmeologically oriented professionally based physical education at higher educational institutions of our country.

Keywords: acmeology, professionally oriented physical education, concept, approach, system, competence, higher educational institution.

Постановка проблеми. Одним із основних завдань фізичного виховання закладів вищої освіти нашої країни $\epsilon$ формування всебічно розвиненої особистості фахівця, здатного до прояву творчості і креативності у професійній і побутовій діяльності, інноваційного пошуку шляхів самореалізації в умовах неперервних змін швидкоплинного інформаційного суспільства, збереження i підтримки гарного стану здоров'я і працездатності впродовж життя [1].

Формування, професійне становлення та розвиток особистості майбутнього фахівця, його самовдосконалення протягом життя, є важливим питанням, на вирішення якого спрямовані наукові дослідження у галузі акмеології. Саме тому, в умовах зростання конкурентності на сучасному ринку праці, професійно орієнтоване фізичне виховання майбутніх фахівців аграрної промисловості повинно здійснюватись на засадах акмеології, що зумовлює пріоритетну спрямованість навчального процесу на формування, розвиток та реалізацію професійно важливих якостей i потенціалу студентської молоді задля досягнення особистісного та професійного акме [1;2].

Аналіз останніх досліджень і публікацій. Науковим пошукам шляхів оптимізації професійної підготовки майбутніх фахівців присвячено наукові праці Г. П. Васяновича, С. М. Вдовича, Н. Я. Вовчастої, О. М. Галуса, 3. В. Гіптерса, Ю. М. Бережного, В. Г. Кременя, Н. В. Кузьміної, Л. В. Козак. Особливості змісту підготовки майбутніх фахівців до умов професійної діяльності визначено у дослідженнях В. I. Андреєва, А. М. Бойко, О. В. Вознюка, О. А. Дубасенюк, Л. Г. Кайдалової, Л. П. Сущенко. Однак, проблеми оптимізації професійно орієнтованого фізичного виховання здобувачів вищої освіти на засадах акмеології та визначення основних підходів концепції його дослідження залишаються поза увагою сучасних науковців.

Мета статті - розглянути особливості системного та компетентнісного підходів концепції дослідження акмеологічно спрямованого професійно орієнтованого фізичного виховання студентів аграрних спеціальностей в умовах освітнього процесу закладу вищої освіти.

Виклад основного матеріалу. Словник сучасної української мови трактує дефініцію «підхід» як «сукупність способів, прийомів розгляду чого небудь, впливу на що небудь, ставлення до чого небудь» [3, с. 969].

У науковій літературі науковий підхід визначають, як «методологічній напрям, що вказує досліднику основний вектор дослідження, вибір засобів та методів». Він зумовлює вибір стратегії дослідження, методологічної платформи, на якій грунтуються погляди науковця при вивченні того чи іншого питання [4].

На нашу думку, концепцію дослідження професійно орієнтованого фізичного виховання майбутніх аграріїв на акмеологічних засадах слід 
розглядати, насамперед, з позицій системного та компетентнісного підходів.

Дослідники Н. Т. Тверезовська і В. В. Сидорко, вивчаючи особливості системного підходу, стверджують, що підхід - це «категорія, яка включає в себе поняття «стратегія» навчання та виступає основною системоутворюючою категорією, що визначає вибір і процесуальну закономірність компонентів системи навчання» [5, с. 158$]$.

Визначення поняття «система» бере свій початок ще 3 античних часів. Розкриваючи сутність дефініції «система», Аристотель стверджував, що «ціле більше суми його частин» $[6$, с. 50].

Гегель, застосовуючи системний підхід до вивчення дійсності, звертає увагу на ієрархічність побудови реальності. Він вважає, що існування системи визначається наявністю складових, між якими існує певна взаємодія. На думку Гегеля, у якості системи можна розглядати практично всі об’єкти реальності [7, с. 121].

Активне вивчення та розробка системного підходу розпочались в середині XX століття і пов'язані із дослідженням і використанням на практиці складних багатокомпонентних систем. Започаткування та розвитку системний підхід набуває у працях науковців різних напрямів, а саме: загальної теорії систем, кібернетики філософії, фізіології та психології [8, с. 23-82; 9-15]. Зазначимо, що перші наукові дослідження 3 розробки поняття «система» були здійснені вченими саме у галузі природничих та математичних наук.

3 середини $\mathrm{XX}$ століття розпочався активний етап розробки $\mathrm{i}$ обгрунтування методологічних аспектів дослідження складних об'єктів у соціології, філософії, педагогіці та психології. Вивчення та розробка системного підходу здійснювалися за двома напрямами - прикладним i загальнотеоретичним. За прикладним напрямом здійснювалися науковотеоретичні дослідження «систем» в конкретних науках (М. М. Амосов, Б. Г. Ананьєв, П. К. Анохін, В. Кузьмін та ін.). Загальнотеоретичний (методологічний) напрям передбачав створення «загальної теорії систем» як методологічної основи наукових досліджень у різних галузях науки [16].

Основним поняттям у системному підході $\epsilon$ «система». Однак, думки науковців щодо визначення даного поняття дещо відрізняються. Дослідники Ю. Бех і А. Слєпцов визначають систему, як «сукупність об'єктів 3 їх відносинами і зв’язками», якій властиві наступні ознаки [17]:

- цілісність (певна незалежність системи від зовнішнього середовища і від інших систем);

- зв'язність (наявність зв'язків між складовими, що дозволяють за допомогою переходів від однієї складової до іншої, з’єднувати декілька будьяких складових системи);

- функція (наявність цілей, які не є простою сумою цілей складових, що належать системі).

С. Бір визначає систему, як «все, що складається з пов’язаних одна з одною частин» [18]. На думку Р. Беллмана, І. Гліксберга та О. Гросса система - це «комплекс взаємодіючих компонентів» [19]. Р. Акофф вважає, що система - «це 
незлічена кількість взаємопов'язаних елементів. Не існує жодної сукупності елементів, не пов'язаної з іншою сукупністю» [20]. Узагальнюючим, на нашу думку, є визначення науковців Є. П. Істоміна та А. Г. Соколова, які вважають систему упорядкованою певним чином, невизначену кількість елементів, що взаємопов’язані між собою і створюють цілісну єдність [21].

На думку М. Прокоф’євої, «загальна теорія систем є концептуальним аналогом будь-якої науки та педагогіки зокрема». Враховуючи те, що ніяка модель не може створюватись безсистемно, дослідниця стверджує що моделювання та система нерозривно пов'язані між собою, а загальна теорія систем і системний підхід становлять методологічну основу будь-якого моделювання [22, с.316].

О. Н. Жаріков, В. І. Королевська, С. М. Хохлов виділяють наступні принципи, на яких грунтується системний підхід [23, с. 18]:

- єдності - одночасне дослідження системи як єдиного цілого i як сукупності складових;

- розвитку - урахування змінюваності системи, їі можливості розвиватись і накопичувати інформацію, зважаючи на динаміку навколишнього середовища;

- глобальної мети - відповідальність за вибір глобальної мети. Оптимальний варіант для будь-якої підсистеми не є таким для усієї системи;

- функціональності - сумісний розгляд функцій та структури системи, при якому перевага надається функціям над структурою;

- децентралізації - поєднання децентралізації і централізації;

- ієрархії - урахування супідрядності і ранжування складових;

- невизначеності - урахування ймовірності настання події;

- організованості - ступінь виконання рішень і висновків.

Широкого використання системний підхід набуває у 70-80 роках минулого століття у працях дослідників-педагогів. 3 позицій системного підходу розглядаються особливості змісту, структури і функцій освітнього процесу в загальноосвітніх школах і закладах вищої освіти, відбувається осмислення цілісної побудови навчально-виховного процесу в ЗВО [24-26].

Вітчизняні і закордонні дослідники, розглядаючи фізичне виховання як підгрунтя освітнього процесу і професійного довголіття, стверджують, що на основі системного підходу можливо об'єднати численні галузі психології i «знайти спільну мову між педагогікою, психологією, фізичним вихованням та суміжними дисциплінами» [26-31].

Визначаючи основну ідею системного аналізу, дослідник А. Лігоцький наголошує на необхідності розгляду системи (моделі системи), як цілого, шукаючи нові підходи не в поділі та спрощенні, а в цілісності та взаємозв'язку. На його думку, об'єктом системного аналізу може бути [31, с. 13]:

- порівняння кількох систем, що виконують спільне завдання;

- дослідження змін системи у іiі розвитку;

- вивчення поведінки системи, «зануреної» у зовнішнє середовище.

Важливим результатом наукових досліджень у галузі педагогічної системології стало виокремлення педагогічних систем 3 кола соціальних i 
визначення їх специфічних особливостей. Розглянемо більш детально поняття «педагогічна система».

За визначенням Н. В. Кузьміної, «педагогічна система» - це «сукупність взаємопов'язаних структурних і функціональних складових, підпорядкованих меті виховання, освіті та навчанню підростаючого покоління і дорослих людей» [32].

Дослідник С. А. Фаренік визначає наступні етапи реалізації системного підходу [33]:

- визначення проблеми дослідження;

- визначення призначення системи;

- визначення змінних і взаємозв'язків між ними;

- визначення функцій і структури системи;

- визначення зовнішнього середовища системи;

- генерування та визначення альтернативних потоків;

- визначення ресурсів, необхідних для реалізації можливих варіантів;

- визначення наявності ресурсів;

- визначення ефективності і вибір оптимального варіанту;

- впровадження обраного варіанту та корегування дій.

На кожному з етапів дослідження застосовуються різні методи і прийоми, вибір яких залежить від змісту завдання [34].

Дослідниця С. В. Коновець підкреслює, що «принцип системності передбачає з'ясування об'єктивності з погляду існуючого у світі всезагального взаємозв'язку усіх предметів і явищ, тобто системність, комплексність істинного знання про об'єкт дослідження виступає необхідним відображенням системних взаємозв'язків, існуючих у самій об'єктивній дійсності, різнобічним і багаторівневим аналізом досліджуваної педагогічної реальності» [35, с. 21]. Тому підсистеми, що $\epsilon$ складовими системи, можна розглядати, як самостійні [36, с. 423].

Таким чином, можна стверджувати, що дослідження акмеологічно спрямованого професійно орієнтованого фізичного виховання 3 позицій системного підходу дозволяє здійснити адекватне визначення проблем та побудувати ефективну стратегію їх вирішення. Даний підхід спрямовує дослідження на розкриття цілісності об'єкту та механізмів, що забезпечують таку цілісність, на виявлення різних типів зв'язків складного об'єкту та зведення їх в єдину систему. Це дає можливість розглядати вказаний процес в єдності його структурних і функціональних компонентів:

- мета системи - формування акмеологічно спрямованої професійної фізичної готовності;

- управлінська підсистема, зокрема, викладач;

- підсистема, яка управляється, зокрема, студент;

- взаємодія й взаємини цих підсистем;

- зміст діяльності системи - зміст акмеологічно спрямованого професійно орієнтованого фізичного виховання;

- засоби, що забезпечують роботу системи - засоби професійно орієнтованого фізичного виховання, організаційні форми роботи, акмеологічні технології навчання та розвитку; 
Журнал«Герспективитаінноваціїнаукиљ

(Серія «Гедагогіка», Серія «Гиихологія», Серія «Медицина»

№2(7) 2022

- методи роботи системи - методи формування акмеологічно спрямованої професійної фізичної готовності;

- продукт роботи системи - акмеологічно спрямована професійна фізична готовність студентів аграрних спеціальностей.

Одним із основних завдань системи освіти нашої країни є забезпечення умов для розвитку і самореалізації кожної особистості і покращення якості освіти випускників закладів вищої освіти. У зв'язку з цим, підготовку майбутніх кваліфікованих фахівців до умов професійної діяльності доцільно розглядати 3 позицій компетентнісного підходу [37].

Дослідженням особливостей реалізації компетентнісного підходу у освітньому процесі закладів вищої освіти присвячено наукові праці О. А. Дубасенюк, В. В. Желанової, О. Плахотнік, О. Безносюк, Л. Овсієнко, В. С. Біскула, Г. П. Шевченко, Н. І. Левун [38-45].

На думку О. І. Гулай, безумовною перевагою компетентнісного підходу $є$ те, що такий підхід до навчального процесу дає можливість визначити його результативно-цільове спрямування [46]. Дослідниця I. Марчук визначає впровадження компетентнісного підходу в освітній процес основною умовою покращення якості освіти [47, с. 23].

Г. П. Шевченко вважає, що методологічні засади компетентнісного підходу у закладах вищої освіти зумовлені положенням про необхідність впровадження творчо-дієвого навчання, що сприяє засвоєнню знань, умінь, навичок, особистісному розвитку студентства та самовдосконаленню особистості. На їі думку, компетентнісний підхід спрямований на всебічний розвиток студента не тільки в якості фахівця-професіонала у конкретній професійній діяльності, а і як особистості, що прагне до самовдосконалення, творчого розвитку i самореалізації [43; 45].

За твердженням Т. К. Андрющенко, впровадження компетентнісного підходу в освітній процес детермінує його практичну спрямованість, що характеризується особистісним та діяльнісним аспектами. Такий підхід зобов'язує відводити основну роль не засвоєнню студентами документально визначених знань, умінь і навичок, а формуванню й розвитку у них здатності самостійно діяти, адекватно застосовуючи знання та суб' єктний досвід у різних життєвих ситуаціях [48, с. 124; 49].

Зважаючи на думку науковців, метою та результатом реалізації компетентісного підходу у освітньому процесі вищої школи можна визначити не тільки обізнаність і володіння вміннями і навичками, а й здатність вирішувати проблемні ситуації у професійній діяльності і особистісних стосунках.

Аналізуючи підходи до вивчення навчально-виховної та фізкультурнооздоровчої діяльності студентів закладів вищої освіти, Г. П. Грибан стверджує, що компетентнісний підхід об'єднує провідні ідеї і принципи реалізації наступних підходів [50, с. 96]:

- діяльнісного i особистісно-діяльнісного, «оскільки фізкультурнооздоровча компетентність безпосередньо виявляється в навчальній i 
позанавчальній діяльності 3 фізичного виховання i пов'язана 3 виявом, прийняттям і вирішенням багатьох проблем і завдань» [50, с. 96];

- особистісно-орієнтованого, що «зумовлено його спрямованістю на фізкультурно-оздоровчі потреби і можливості, цілі й цінності, становлення фізичних, естетичних і духовних рис особистості» [50, с. 96];

- акмеологічного, який $\epsilon$ необхідною передумовою i готовністю, що визначає прагнення особистості до здійснення фізкультурно-оздоровчої діяльності [50, с. 96];

- андрогогічного, що базується на стимулюванні студента до самостійного засвоєння знань, умінь і навиків, залучення до здорового способу життя, планування і корекції власної фізкультурно-оздоровчої діяльності, гнучкої адаптації до мінливих умов професійної діяльності [50, с. 96].

У системі фізичного виховання вищої школи компетентнісний підхід реалізується саме в освітньому процесі 3 професійно орієнтованого фізичного виховання. На думку О. А. Чернявської, важливого значення набуває розробка та впровадження нових підходів до формування професійно орієнтованої компетенції в процесі фізичного виховання. При цьому, необхідною умовою освітнього процесу авторка вважає поєднання всіх форм організації фізичного виховання у закладі освіти [51, с. 142].

Висновки. Дослідження організації професійно орієнтованого фізичного виховання на засадах акмеології з позицій системного підходу вимагає осмислення не тільки сутності цього процесу, a i його структурно-змістових сторін у логічному, психологічному i професійно-змістовному аспектах. Цей підхід дозволяє розглядати процес формування акмеологічно спрямованої професійної фізичної готовності студентів аграрних спеціальностей як цілісну динамічну систему, визначити особливості іiі компонентів, категорій, дослідити характер і механізми зв'язків між ними й на цій основі вибудувати модель організації професійно орієнтованого фізичного виховання на засадах акмеології.

Використання компетентнісного підходу в освітньому процесі зумовлює його практичну зорієнтованість, що характеризується особистісним та діяльнісним аспектами. За таких умов основна роль належить не засвоєнню студентами документально визначених знань, умінь і навичок, а формуванню й розвитку у них здатності самостійно діяти, адекватно застосовуючи знання та суб’єктний досвід у різних життєвих, у тому числі і професійних, ситуаціях. Таким чином, метою та результатом реалізації компетентісного підходу у освітньому процесі вищої школи можемо визначити не лише обізнаність $i$ володіння вміннями і навичками, а й здатність вирішувати проблемні ситуації у професійній діяльності і особистісних стосунках.

\section{Jimepamypa:}

1. Сахненко А. В. Акмеологічні засади організації професійно орієнтованого фізичного виховання студентів аграрних спеціальностей: дисс. ... докт. філософії: 017. Суми, 2020. 271 с.

2. Сахненко А. В. Системний підхід до дослідження формування акмеологічноспрямованої професійної фізичної готовності студентів аграрних спеціальностей. Paradigmatic view on the concept of world science. (Toronto, august 21, 2020) C. 81-83. 
Журнал«Герспективитаінноваціїнауки»

(Серія «Гедагогіка», Серія«ГТихологія», Серія«Медицине»

№2(7) 2022

3. Великий тлумачний словник сучасної української мови / гол. ред.. В .Т. Бусел. К., Ірпінь: ВТФ Перун, 2005.

4. Introduction to research and research methods. Режим доступу: http://www.brad.ac.uk/ management/media/management/els/Introduction-to-Research-and-Research-Methods.pdf (дата звернення: 26.04.2020)

5. Сидорко В. В., Тверезовська Н. Т. Системний підхід як методологія реалізації між предметних зв'язків у навчальному процесі. Вісник Національного університету оборони України. 2014. № 1 (38). С. 157-161.

6. Андрущенко И. В., Вусатюк О. А., Линецкий С. В. Философский словарь. Киев: A.C.K., 2006.

7. Овсянников М. Ф. Гегель (Мыслители прошлого). М.: Мысль, 1971.

8. Берталанфи Л. фон. Общая теория систем: критический обзор. Сборник переводов: Исследования по общей теории систем. М.: Прогресс, 1969.

9. Винер Н. Кибернетика, или Управление и связь в животном и машине. М.: Наука, 1983.

10. Гиг Дж. Прикладная общая теория систем. М.: Мир, 1981.

11. Моисеев Н. Н. Математические задачи системного анализа. М.: Наука, 1981.

12. Садовский И. Н., Блауберг И. В., Юдин Э. Г. Системный подход: предпосылки, проблемы, трудности. М., 1968.

13. Ломов Б. Ф. О системном подходе в психологии. Вопросы психологии. 1975. № 2. C. $31-45$.

14. Анохин П. К. Философские аспекты теории функциональной системы. М.: Наука, 1978.

15. Эшби У. Росс. Общая теория систем как новая дисциплина. Исследования по общей теории систем. М.: Прогресс, 1969. С. 125-142.

16. Ковальчук В. А. Становлення системного підходу дослідження педагогічних об'єктів та явищ. Дослідницький компонент у діяльності загальноосвітніх навчальних закладів та позашкільних закладів освіти: ретроспектива $i$ перспектива: матеріали Всеукраїнської науково-практичної конференції. (Київ, 21 листопада 2013 р.) Київ: Інститут обдарованої дитини, 2013. С. 32-38.

17.Бех Ю. В., Слєпцов А. І. Філософські проблеми сучасного управління складними системами: ідеї, принципи і моделі. К.: Вид-во НПУ імені М. П. Драгоманова, 2012.

18. Бир С. Кибернетика и менеджмент. М.: «УРСС», 2006.

19.Беллман Р., Гликсберг И., Гросс О. Математическое моделирование. Процессы в сложных экономических и экологических системах. М.: ИИЛ, 1962.

20. Акофф Р. Акофф о менеджменте. СПб.: Питер, 2002.

21. Истомин Е. П., Соколов А. Г. Теория организаций: системный подход. СПб.: ООО «Андреевский издательский дом», 2009.

22. Прокоф'єва М. Системний підхід у підготовці майбутнього педагога до реалізації диференційованого навчання. Проблеми підготовки сучасного вчителя. 2011. № 4. С. 315-322.

23. Жариков О. Н., Королевская В. И., Хохлов С. Н. Системный подход к управлению. М.: ЮНИТИ-ДАНА, 2001.

24. Арсеньев А. М., Королев Ф. Ф. Методологические проблемы социалистической педагогики. Проблемы сочиалистической педагогики. М.: Педагогика, 1970. С. 10-40.

25. Ильина Т. А. Структурно-системный подход к организации обучения. М.: Знание, 1978.

26. Раевский Р. Т. Профессионально-прикладная физическая подготовка студентов технических вузов. М.: Высш. шк., 1985.

27. Друзь Ю. Позитивна мотивація як умова успішності навчально-ігрової діяльності студентів. Рідна школа. 2000. № 7. С. 56-57.

28. Зуев К. Е., Блохин В. И., Морозов В. А. Формирование личности инженера в вузе. К.: Издательство Киевского гос. университета им. Т. Шевченко, 1982.

29. Кокун О. Фізична культура і спорт як фактор підвищення адаптаційних можливостей студентів. Вісник Технологічного університету Поділля. 2002. № 5. С. 47-50. 
30. Макаров Р. Н. Основы формирования профессиональной надежности летного состава. М.: Воздушный транспорт, 1990.

31. Лігоцький А. О. Проектування освітніх систем. К.: Техніка, 1994.

32. Кузьмина Н. В. Предмет акмеологии. СПб: Политехника, 2002.

33. Фаренік С. А. Логіка і методологія наукового дослідження. К.: Видавництво УАДУ, 2000.

34. Фаренік С. А. Управління соціальними процесами: побудова та реалізація соціальних моделей. К.: Видавництво УАДУ, 2003.

35. Коновець С. В. Системний підхід до професійно-педагогічної діяльності вчителя як до творчого процесу. Науковий часопис НПУ імені М. П. Драгоманова. Серія 16, Творча особистість учителя: проблеми теорії і практики. 2013. № 19 (29). С. 21-24.

36. Гончаренко С. У. Український педагогічний енциклопедичний словник. Рівне: Волинські береги, 2011.

37. Чернігівська С. А. Методологічні та теоретичні основи навчання студентів інженерних спеціальностей у ході формування компетентностей 3 фізичного виховання. Педагогічні аспекти професійної підготовки майбутнього фахівия з фізичного виховання та cnopmy. 2015. № 129. C. 279-283.

38. Біскул В. С. Принципи та технології компетентнісного підходу до формування професійної кар’єрної студентської молоді. Sociology. 2016. № 5 (133). С. 61-67.

39. Дубасенюк О. А. Професійна педагогічна освіта: компетентнісний підхід. Житомир: Вид-во ЖДУ ім. І. Франка, 2011.

40. Желанова В. В. Рефлексивна складова професійної компетентності як результативноцільова основа контекстного навчання майбутнього вчителя початкових класів у ВНЗ. Вісник Луганського національного університету імені Тараса Шевченка. Педагогічні науки. 2012. № 19 (3). С. 247-260. Режим доступу: http://nbuv.gov.ua/UJRN/vlup_2012_19(3)_32.

41. Желанова В. В. Культуротворчі аспекти професійної компетентності майбутнього педагога. Вісник Луганського національного університету імені Тараса Шевченка. Педагогічні науки. 2017. № 7 (2). С. 48-55. Режим доступу: http://nbuv.gov.ua/UJRN/vlup_2017_7(2)_9.

42. Левун Н. I. Компетентнісний підхід у підготовці майбутніх педагогів як пріоритет модернізації вищої освіти України. Проблемы современного педагогического образования. 2014. № 43 (1). С. 99-104.

43. Овсієнко Л. Компетентнісний підхід до навчання: теоретичний аналіз. Педагогічний процес: теорія і практика. Серія: Педагогіка. 2017. № 2. С. 82-87.

44. Плахотнік О., Безносюк О. Компетентнісний підхід у ВНЗ: проблеми та перспективи. Наукові записки Кіровоградського державного педагогічного університету імені Володимира Винниченка. Сер.: Педагогічні науки. 2013. № 121 (2). С. 200-205. Режим доступу: http://nbuv.gov.ua/UJRN/Nz_p_2013_121(2)_49

45. Шевченко Г. П. Концептуальна сутність компетентнісного підходу: європейський вимір. Реалізація європейського досвіду компетентнісного підходу у вищій школі України. К.: Педагогічна думка, 2009. С. 121-130.

46. Гулай О. I. Компетентнісний підхід як основа нової парадигми освіти. Вісник Національної академії Державної прикордонної служби України. 2009. № 2. С. 41-51.

47. Марчук І. Компетентнісно зорієнтовані технології розвитку особистості в контексті нової української школи. Нова педагогічна думка. 2016. № 4. С. 22-26.

48. Андрющенко Т. К. Формування здоров'язбережувальної компетентності як соціально-педагогічна проблема. Науковий вісник Волинського національного університету імені Лесі Украӥнки. 2012. № 7. С. 123-127.

49. Хольченкова Н. М. Формування здоров'язбережувальної компетентності як сучасна науково-педагогічна проблема. Вісник Чернігівського національного педагогічного університету. Серія: Педагогічні науки. Фізичне виховання та спорт. 2017. № 147 С. 138-141. Режим доступу: http://nbuv.gov.ua/UJRN/VchdpuPN_2017_147(2)_35 
50. Грибан Г. П. Технологія формування фізкультурно-оздоровчих компетентностей у студентів аграріїв. Вісник Запорізького національного університету. Педагогічні науки. 2013. № 1. C. 94-104. Режим доступу: http://nbuv.gov.ua/UJRN/Vznu_ped_2013_1_16.

51. Чернявська О. А. Проблема реалізації компетентнісного підходу у процесі фізичного виховання учнів професійно-технічних навчальних закладів. Слобожанський науковоспортивний вісник. 2012. № 5. С. 140-142.

\section{References:}

1. Sahnenko A. V. Akmeologichni zasadi organizaciï profesijno orientovanogo fizichnogo vihovannja studentiv agrarnih special'nostej: diss. ... dokt. filosofiï: 017. Sumi, 2020. 271 s.

2. Sahnenko A. V. Sistemnij pidhid do doslidzhennja formuvannja akmeologichnosprjamovanoï profesijnoï fizichnoï gotovnosti studentiv agrarnih special'nostej. Paradigmatic view on the concept of world science. (Toronto, august 21, 2020) S. 81-83.

3. Velikij tlumachnij slovnik suchasnoï ukraïns'koï movi / gol. red.. V .T. Busel. K., Irpin': VTF Perun, 2005.

4. Introduction to research and research methods. Rezhim dostupu: http://www.brad.ac.uk/ management/media/management/els/Introduction-to-Research-and-Research-Methods.pdf (data zvernennja: 26.04.2020)

5. Sidorko V. V., Tverezovs'ka N. T. Sistemnij pidhid jak metodologija realizaciï mizh predmetnih zv'jazkiv u navchal'nomu procesi. Visnik Nacional'nogo universitetu oboroni Ukraïni. 2014. № 1 (38). S. 157-161.

6. Andrushhenko I. V., Vusatjuk O. A., Lineckij S. V. Filosofskij slovar'. Kiev: A.S.K., 2006.

7. Ovsjannikov M. F. Gegel' (Mysliteli proshlogo). M.: Mysl', 1971.

8. Bertalanfi L. fon. Obshhaja teorija sistem: kriticheskij obzor. Sbornik perevodov: Issledovanija po obshhej teorii sistem. M.: Progress, 1969.

9. Viner N. Kibernetika, ili Upravlenie i svjaz' v zhivotnom i mashine. M.: Nauka, 1983.

10. Gig Dzh. Prikladnaja obshhaja teorija sistem. M.: Mir, 1981.

11. Moiseev N. N. Matematicheskie zadachi sistemnogo analiza. M.: Nauka, 1981.

12. Sadovskij I. N., Blauberg I. V., Judin Je. G. Sistemnyj podhod: predposylki, problemy, trudnosti. M., 1968.

13.Lomov B. F. O sistemnom podhode v psihologii. Voprosy psihologii. 1975. № 2. S. 31-45.

14. Anohin P. K. Filosofskie aspekty teorii funkcional'noj sistemy. M.: Nauka, 1978.

15. Jeshbi U. Ross. Obshhaja teorija sistem kak novaja disciplina. Issledovanija po obshhej teorii sistem. M.: Progress, 1969. S. 125-142.

16.Koval'chuk V. A. Stanovlennja sistemnogo pidhodu doslidzhennja pedagogichnih ob'ektiv ta javishh. Doslidnic'kij komponent u dijal'nosti zagal'noosvitnih navchal'nih zakladiv ta pozashkil'nih zakladiv osviti: retrospektiva i perspektiva: materiali Vseukraïns'koï naukovo-praktichnoï konferenciï. (Kiï, 21 listopada 2013 r.) Kiïv: Institut obdarovanoï ditini, 2013. S. 32-38.

17. Beh Ju. V., Slepcov A. I. Filosofs'ki problemi suchasnogo upravlinnja skladnimi sistemami: ideï, principi i modeli. K.: Vid-vo NPU imeni M. P. Dragomanova, 2012.

18. Bir S. Kibernetika i menedzhment. M.: «URSS», 2006.

19. Bellman R., Gliksberg I., Gross O. Matematicheskoe modelirovanie. Processy v slozhnyh jekonomicheskih i jekologicheskih sistemah. M.: IIL, 1962.

20. Akoff R. Akoff o menedzhmente. SPb.: Piter, 2002.

21. Istomin E. P., Sokolov A. G. Teorija organizacij: sistemnyj podhod. SPb.: OOO «Andreevskij izdatel'skij dom», 2009.

22. Prokof'єva M. Sistemnij pidhid u pidgotovci majbutn'ogo pedagoga do realizaciï diferencijovanogo navchannja. Problemi pidgotovki suchasnogo vchitelja. 2011. № 4. S. 315-322.

23. Zharikov O. N., Korolevskaja V. I., Hohlov S. N. Sistemnyj podhod k upravleniju. M.: JuNITI-DANA, 2001. 
24. Arsen'ev A. M., Korolev F. F. Metodologicheskie problemy socialisticheskoj pedagogiki. Problemy socialisticheskoj pedagogiki. M.: Pedagogika, 1970. S. 10-40.

25. Il'ina T. A. Strukturno-sistemnyj podhod k organizacii obuchenija. M.: Znanie, 1978.

26. Raevskij R. T. Professional'no-prikladnaja fizicheskaja podgotovka studentov tehnicheskih vuzov. M.: Vyssh. shk., 1985.

27. Druz' Ju. Pozitivna motivacija jak umova uspishnosti navchal'no-igrovoï dijal'nosti studentiv. Ridna shkola. 2000. № 7. S. 56-57.

28. Zuev K. E., Blohin V. I., Morozov V. A. Formirovanie lichnosti inzhenera v vuze. K.: Izdatel'stvo Kievskogo gos. universiteta im. T. Shevchenko, 1982.

29. Kokun O. Fizichna kul'tura i sport jak faktor pidvishhennja adaptacijnih mozhlivostej studentiv. Visnik Tehnologichnogo universitetu Podillja. 2002. № 5. S. 47-50.

30. Makarov R. N. Osnovy formirovanija professional'noj nadezhnosti letnogo sostava. M.: Vozdushnyj transport, 1990.

31. Ligoc'kij A. O. Proektuvannja osvitnih sistem. K.: Tehnika, 1994.

32. Kuz'mina N. V. Predmet akmeologii. SPb: Politehnika, 2002.

33. Farenik S. A. Logika i metodologija naukovogo doslidzhennja. K.: Vidavnictvo UADU, 2000.

34. Farenik S. A. Upravlinnja social'nimi procesami: pobudova ta realizacija social'nih modelej. K.: Vidavnictvo UADU, 2003.

35. Konovec' S. V. Sistemnij pidhid do profesijno-pedagogichnoï dijal'nosti vchitelja jak do tvorchogo procesu. Naukovij chasopis NPU imeni M. P. Dragomanova. Serija 16, Tvorcha osobistist' uchitelja: problemi teoriï i praktiki. 2013. № 19 (29). S. 21-24.

36. Goncharenko S. U. Ukraïns'kij pedagogichnij enciklopedichnij slovnik. Rivne: Volins'ki beregi, 2011.

37. Chernigivs'ka S. A. Metodologichni ta teoretichni osnovi navchannja studentiv inzhenernih special'nostej $\mathrm{u}$ hodi formuvannja kompetentnostej $\mathrm{z}$ fizichnogo vihovannja. Pedagogichni aspekti profesijnoï pidgotovki majbutn'ogo fahivcja $\mathrm{z}$ fizichnogo vihovannja ta sportu. 2015. № 129. S. 279-283.

38. Biskul V. S. Principi ta tehnologiï kompetentnisnogo pidhodu do formuvannja profesijnoï kar’ernoï students'koï molodi. Sociology. 2016. № 5 (133). S. 61-67.

39. Dubasenjuk O. A. Profesijna pedagogichna osvita: kompetentnisnij pidhid. Zhitomir: Vid-vo ZhDU im. I. Franka, 2011.

40. Zhelanova V. V. Refleksivna skladova profesijnoï kompetentnosti jak rezul'tativno-cil'ova osnova kontekstnogo navchannja majbutn'ogo vchitelja pochatkovih klasiv u VNZ. Visnik Lugans'kogo nacional'nogo universitetu imeni Tarasa Shevchenka. Pedagogichni nauki. 2012. № 19 (3). S. 247-260. Rezhim dostupu: http://nbuv.gov.ua/UJRN/vlup_2012_19(3)_32.

41. Zhelanova V. V. Kul'turotvorchi aspekti profesijnoï kompetentnosti majbutn'ogo pedagoga. Visnik Lugans'kogo nacional'nogo universitetu imeni Tarasa Shevchenka. Pedagogichni nauki. 2017. № 7 (2). S. 48-55. Rezhim dostupu: http://nbuv.gov.ua/UJRN/vlup_2017_7(2)_9.

42. Levun N. I. Kompetentnisnij pidhid u pidgotovci majbutnih pedagogiv jak prioritet modernizaciï vishhoï osviti Ukraïni. Problemy sovremennogo pedagogicheskogo obrazovanija. 2014. № 43 (1). S. 99-104.

43. Ovsienko L. Kompetentnisnij pidhid do navchannja: teoretichnij analiz. Pedagogichnij proces: teorija i praktika. Serija: Pedagogika. 2017. № 2. S. 82-87.

44. Plahotnik O., Beznosjuk O. Kompetentnisnij pidhid u VNZ: problemi ta perspektivi. Naukovi zapiski Kirovograds'kogo derzhavnogo pedagogichnogo universitetu imeni Volodimira Vinnichenka. Ser.: Pedagogichni nauki. 2013. № 121 (2). S. 200-205. Rezhim dostupu: http://nbuv.gov.ua/UJRN/Nz_p_2013_121(2)_49

45. Shevchenko G. P. Konceptual'na sutnist' kompetentnisnogo pidhodu: evropejs'kij vimir. Realizacija evropejs'kogo dosvidu kompetentnisnogo pidhodu u vishhij shkoli Ukraïni. K.: Pedagogichna dumka, 2009. S. 121-130. 
46. Gulaj O. I. Kompetentnisnij pidhid jak osnova novoï paradigmi osviti. Visnik Nacional'noï akademiï Derzhavnoï prikordonnoï sluzhbi Ukraïni. 2009. № 2. S. 41-51.

47. Marchuk I. Kompetentnisno zorientovani tehnologiï rozvitku osobistosti v konteksti novoï ukraïns'koï shkoli. Nova pedagogichna dumka. 2016. № 4. S. 22-26.

48. Andrjushhenko T. K. Formuvannja zdorov'jazberezhuval'noï kompetentnosti jak social'no-pedagogichna problema. Naukovij visnik Volins'kogo nacional'nogo universitetu imeni Lesi Ukraïnki. 2012. № 7. S. 123-127.

49. Hol'chenkova N. M. Formuvannja zdorov'jazberezhuval'noï kompetentnosti jak suchasna naukovo-pedagogichna problema. Visnik Chernigivs'kogo nacional'nogo pedagogichnogo universitetu. Serija: Pedagogichni nauki. Fizichne vihovannja ta sport. 2017. № 147 S. 138-141. Rezhim dostupu: http://nbuv.gov.ua/UJRN/VchdpuPN_2017_147(2)__35

50. Griban G. P. Tehnologija formuvannja fizkul'turno-ozdorovchih kompetentnostej u studentiv agrariïv. Visnik Zaporiz'kogo nacional'nogo universitetu. Pedagogichni nauki. 2013. № 1. S. 94-104. Rezhim dostupu: http://nbuv.gov.ua/UJRN/Vznu_ped_2013_1_16.

51. Chernjavs'ka O. A. Problema realizaciï kompetentnisnogo pidhodu u procesi fizichnogo vihovannja uchniv profesijno-tehnichnih navchal'nih zakladiv. Slobozhans'kij naukovo-sportivnij visnik. 2012. № 5. S. 140-142. 